\title{
Lashers and Leviathan: The 1954 Coalminers' Strike in Colonial Zimbabwe*
}

\author{
IAN PHIMISTER
}

Summary: In 1953 Southern Rhodesia's (Zimbabwe's) only coal mine, Wankie Colliery, was taken over by the Anglo American Corporation of South Africa. The colliery's new owners soon discovered that the elimination of "hand lashing" (shovelling of coal) was the key to better productivity and expanded output. Coal cutting machinery was installed wherever possible, but in the colliery's two oldest shafts existing mining methods were too deeply entrenched and consequently too expensive simply to be swept away. Instead Anglo American attempted to reinforce colonial production relations. Supervision underground was tightened up, and the degree of "self-regulation" enjoyed by lashers in determining the amount of work they did was limited. The introduction of a new mine tub designed to increase productivity precipitated strike action in February 1954 by the colliery's entire black labour force.

The mining revolution which transformed the Southern African subcontinent after the discovery of diamonds and especially gold in the last thirty years or so of the nineteenth century was fuelled initially by wood and increasingly by coal. While the gold mines of the Witwatersrand were supplied by collieries in the Transvaal and Natal, the mining industry which developed in colonial Zimbabwe, or Southern Rhodesia as it was then, depended on a single coal deposit in the remote north-western corner of the country.' Known to generations of whites as "coalopolis", and less affectionately remembered as "Gu za unka a Malahl'eni, the place that stinks", by black miners, this was Wankie colliery. ${ }^{2}$

As the only colliery of any significance between the Limpopo River and the Congo-Zambezi watershed (see Map 1), Wankie occupied a

* Financial support from the Human Sciences Research Council is gratefully acknowledged. It is not, of course, to be held responsible for the opinions expressed or the conclusions arrived at in this paper.

${ }^{1}$ For a general overview, see especially S. Marks, "Southern and Central Africa, 18861910", in R. Oliver and G. Sanderson (eds), Cambridge History of Africa, VI, 1870 1905 (Cambridge, 1985).

2 NB3/L/6, Native Commissioner, Sebungwe, to Chief Native Commissioner, Bulawayo, 23 March 1906. Unless otherwise stated, all file references are to the National Archives, Harare, Zimbsbwe.

International Review of Social History 39 (1994), pp. 165-196 
pivotal role in the economic and social history. of this vast region until its importance was somewhat diminished by the completion of the Kariba hydroelectric scheme in 1961. Before that date, however, the colliery's position was unchallenged. Drawing its labour force from throughout Central Africa (Map 2), Wankie supplied coal to the copper mines of Katanga, in modern-day Zaire, and Northern Rhodesia, now Zambia, as well as to the mines and industries of Southern Rhodesia itself. "There can be no doubt of the absolute and impressive dependence of the Rhodesias on the Wankie coalfield," concluded an official investigation in 1949. "In fact a breakdown of coal extraction would mean a rapid retrocession in the social and economic life of the territories, leading quickly to paralysis. We state this with no wish to be dramatic but merely to put the Wankie coalfield into its right perspective."3

It was precisely this regional importance which had first drawn the attention of one of South Africa's largest mining houses, Anglo American, to Wankie's limited productive capacity. The profitability of Anglo American's extensive interests on the Northern Rhodesian Copperbelt turned on the regular supply of coal, but after years of mismanagement and starved of investment, the colliery was manifestly incapable of meeting the growing demands of its customers. As a result, Anglo American bought Wankie from Britain's Powell Duffryn company at the beginning of 1953, with the express intention of modernizing the colliery and expanding its output as quickly as possible. Yet Anglo American's efforts to improve productivity and increase production soon precipitated a major strike by Wankie's black labour force, the course of which is explored in the three sections which follow. Part one traces the pattern of intervention stamped on the colliery by its new South African owners, while part two examines the strike and its organization in detail. A concluding section attempts to establish the significance of the strike both in terms of Zimbabwe's past and mining historiography more generally.

\section{I}

When Anglo American announced in March 1953 that it had taken a controlling interest in Southern Rhodesia's only coal mine, not everyone was pleased by this latest development in Wankie's chequered career." "Some see in it the first sinister fruits of Federation [between Southern Rhodesia, Northern Rhodesia and Nyasaland], 'leviathan', 'big business',

3 Report of the Wankie Coal Commission (1949), p. 9.

- For the early history of Wankie, see C. van Onselen, "The 1912 Wankie Colliery Strike", Journal of African History, 15 (1974); and I. Phimister, "Coal, Crisis, and Class Struggle: Wankie Colliery, 1918-22", Journal of African History, 33 (1992). 


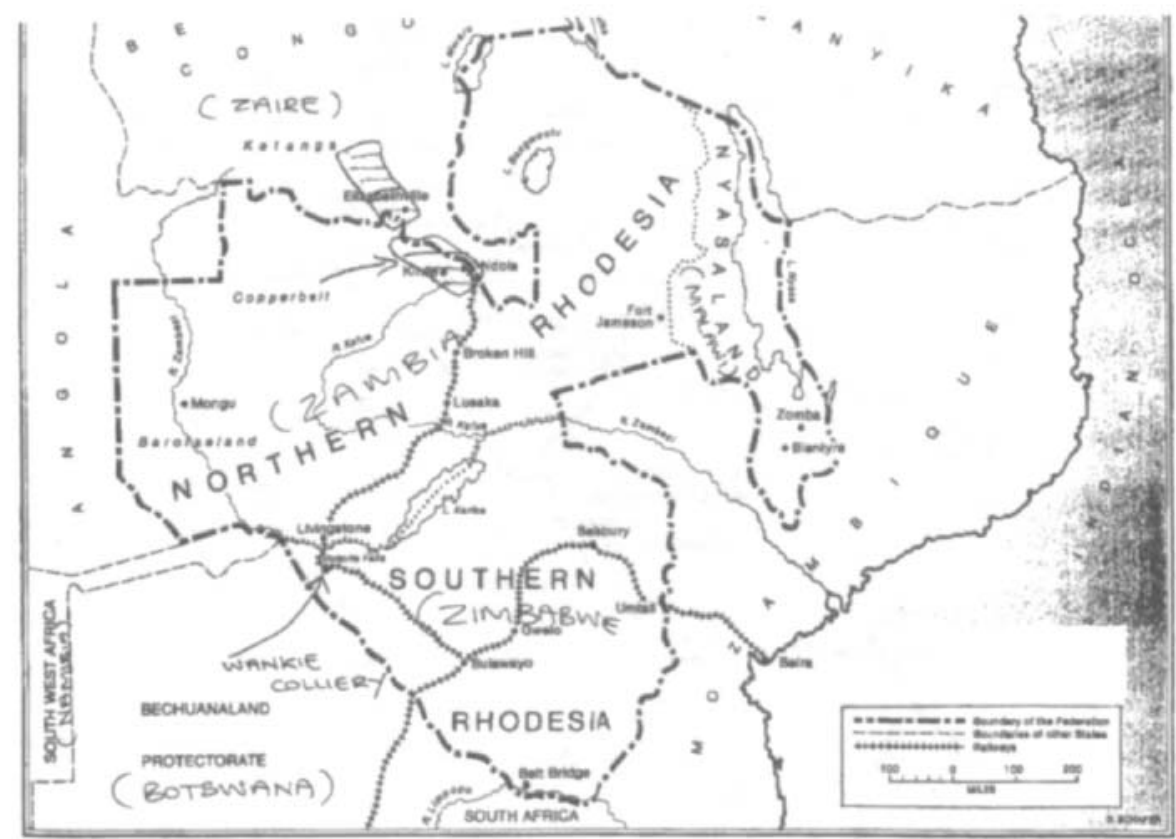

Map 1. Federation of Rhodesia and Nyasaland

'vested interests', 'monopolies', exploiting the gullible Rhodesian, and so forth", warned one editorial. Given Anglo American's "predominant stake in the copper mines", it was feared that "Wankie coal will be sent north in such quantities as to cripple Southern Rhodesia". ${ }^{5}$ Others, though, were far more positive. The Southern Rhodesia Government was given what was described as a cast-iron guarantee that the "full financial and technical strength of the [Anglo American] corporation and its associates will be available to ensure that the Wankie Colliery will within two or three years be brought to a position when it can meet the full requirements of the territories which it serves." "They have shown faith in Rhodesia, faith in the Federal State", concluded a leading industrial journal. "Anglo American is virile, rich, and successful; and evidently its Directors share the belief of most Rhodesians that, if only the Socialists and myopic churchmen in England will give Central Africa a rest from their foolish meddling, there is every prospect of political stability upon which a spectacular economic advance can be founded."

'Rhodesian Mines and Industries, May 1953.

- As cited in Sir Theodore Gregory, Ernest Oppenheimer and the Economic Development of Southern Africa (London, 1962), p. 460, and Rhodesian Mines and Industries, May 1953. 


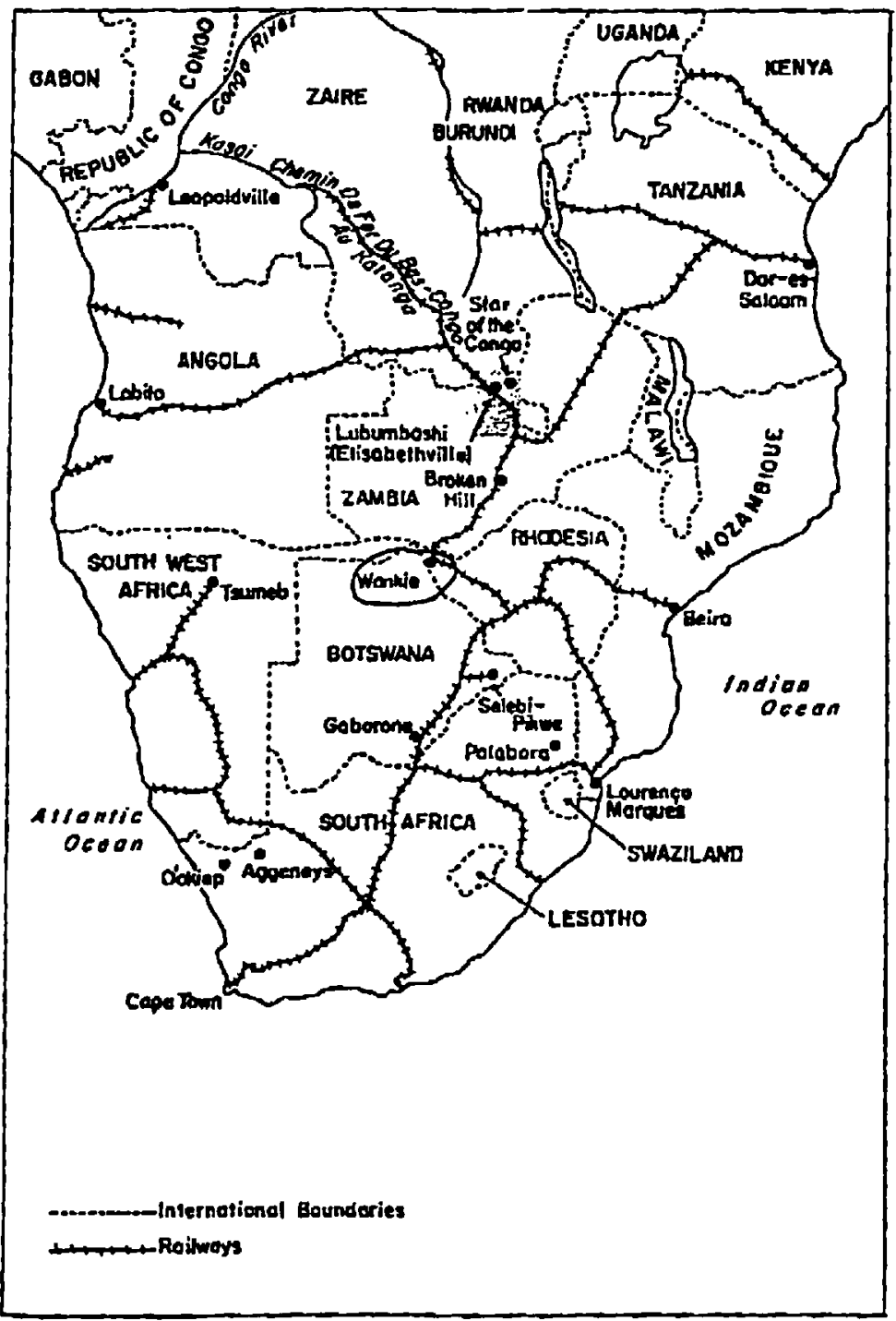

Map 2. Mining centres and railway systems in Southern Africa

The last things likely to have been on Anglo American's mind were the concerns of overseas socialists and churchmen, its mildly liberal corporate image notwithstanding. A Johannesburg-based conglomerate who occasionally demurred at the cruder racist excesses of South Africa's ruling National Party, while simultaneously imposing a grim regime of low wages and migrant labour on its own black workforce, Anglo American's management skills and production practices had been 
honed in the coal and gold mines of the Rand. ${ }^{7}$ Both of them were immediately set to work at Wankie. High on the list of Anglo American's priorities was accelerated development of a third shaft, or colliery, in order to augment production from the much older workings known as No. 1 and No. 2 collieries. A capital programme "costing $£ 5,250,000$ for opening and equipping No. 3 shaft and for general reconstruction" was immediately begun. "The raising of this finance together with wiping out a bank overdraft of $£ 900,000$ presented no difficulties whatever", noted Wankie's newly-appointed chairman. "We soon had all the money required." By 1955 "the capital employed in the business had risen to $£ 9,121,000$ ", a fourfold increase in little over five years. Much of this capital was poured into "construction and development work at No. 3 Colliery", as well as into "reorganising No. 1 Colliery and remodelling No. 2 Colliery to achieve increased dependable output capacity". It was all done, shareholders were assured, "with great drive and diligence". ${ }^{9}$ In much the same period, Wankie's new managers brought their formidable experience to bear on the "need for greater efficiency". Between May and December 1953, they began exploring ways and means of "reorganising the Colliery's underground Native labour force" in order to raise productivity to Transvaal levels. ${ }^{10}$ The South Africans did not have to look far.

Until the late 1940s, "the system of working underground had remained virtually unchanged throughout Wankie's history". Coal was "blasted off the solid" by charges of explosive placed in holes drilled in the coalface. ${ }^{11}$ Although slow and wasteful compared to other methods of mining coal, the system at Wankie had lasted as long as it had primarily because black labour was cheap and plentiful. Such change as subsequently occurred was forced on the colliery by rising costs and an acute shortage of labour, as a result of which electrically driven coal cutting machines were introduced in 1949/1950. The coal cutters operated by making

a semi-circular cut in each face 9ft. into the coal at the centre and about 6 inches deep some $4 \mathrm{ft}$. 6 inches from the floor, thus creating two "free" faces

'For detailed discussion, see, amongst others, D. Innes, Anglo American and the Rise of Modern South Africa (New York, 1984); F. Wilson, Labour in the South African Gold Mines, 1911-1969 (London, 1972); and D. Pallister et al., South Africa Inc. The Oppenheimer Empire (Johannesburg, 1987).

"H.Mss, "The Coulter Family 1801 to 1935, including some personal recollections by T. Coulter", December 1963, p. 80. Privately held.

- Wankie Colliery Company Lid, Report of the Directors for the year ended 31st August 1955, p. 14. See also Report of the Directors for the year ended 31st August 1954, p. 7.

"0 [Garfield] Todd Papers, "Notes on Events leading up to, and the possible causes of the Wankie Strike, February 1954", Wankie, 7 January 1955. Privately held.

"ZCB22/1, proof of evidence, Martin. 
of coal. These faces were then drilled by hand-held electric rotary drills to a pre-determined pattern, the holes terminating 6 inches from the back of the "cut". The holes were charged with explosives and detonators and were fired either electrically or by safety fuse. ${ }^{12}$

With undercutting, "less explosive was used, the blast was more effective and coal was broken into larger chunks", ${ }^{13}$ but as Anglo American already knew, coal cutters could be utilized effectively only in some parts of the existing colliery complex. Only No. 2 Colliery had the shaft capacity to handle large increases in output, and only No. 2 Colliery had "the thick coal [seam] in which the best results from mechanisation were to be expected". The geological faulting so far encountered there was not regarded as "so severe as seriously to compromise mechanisation". ${ }^{14}$

At No. 1 Colliery, where some workings dated back almost to the turn of the century, even Powell Duffryn had simply continued to extract coal in the same bad old way as before. Effort was dispersed over a large number of active working faces, and because "blasting off the solid' involved lashing boys being employed in turning back the coal to enable the jackhammer operators to get to the face to drill another round, this meant double handling in all development coal, with a consequent adverse effect on costs." 15 In both collieries, moreover, all coal, whether initially "blasted down" or undercut, was subsequently loaded and transported in exactly the same way. Coal was shovelled or "lashed" into tubs which were then pushed or "trammed" to the nearest section way of the endless rope haulage. Once coupled to the haulage, the tubs were pulled to the surface, emptied, and returned underground. Like others before them, Anglo American soon saw where a large part of the problem lay. Output per manshift turned primarily on the number of tubs "lashed". "I cannot say that all in all the whole set up of our labour revolves around lashing boys but it is very nearly that", the Coal Commission had been told by the colliery's then mine manager in 1949. "It is the bottleneck of the colliery."16

Although the problem was simple enough to identify, this did not make it any easier to resolve. At the end of the 1940s and the start of the 1950s, neither the colliery's previous owners nor Powell Duffryn had possessed sufficient determination or, more to the point, large enough resources to grapple with it in all its manifestations. If production was not to be interrupted, then action would be required on several

12 ZMM, File 361/1376, "Production of Coal and By-products: Wankie Coalfield", November 1959.

is Bulawayo Chronicle, 9 June 1949.

it ZCB22/1, proof of evidence, Martin.

is Report of the Wankie Coal Commission, p. 21.

${ }^{16} \mathrm{ZCB} 2 / 2 / 1$, evidence taken from Martin and Ocrtel. 
fronts. Unlike its predecessors, however, Anglo American had not only the will but also the way to stamp its authority on the organization of work underground. In doing so, it pursued several strategies simultaneously. Over the longer term, No. 3 Colliery scheduled to come into full production in the second half of 1954, was planned and equipped from top to bottom for mechanized work. Mechanically developed and won coal would be carried to the surface by the latest in belt conveyors. "At the face electrically powered loading machines are employed to gather up the coal," explained a later report, "and to deposit it into electrically driven cars having a capacity of 8 tons, and these cars carry the coal from the faces to the end of the belt conveyor system, where they discharge their load and return again to be filled at the face." The elimination of "hand lashing" and conventional rope haulages, Anglo American's managers were convinced, was the key both to better productivity and expanded output. ${ }^{17}$

But sweeping changes of this kind were only practically possible where completely new shafts were being sunk. Compared to the free hand which it enjoyed in developing No. 3 Colliery, Anglo American's room for manoeuvre was severely circumscribed in Wankie's older workings. The South Africans found themselves restricted at virtually every turn by the way in which No. 1 and No. 2 Collieries had originally been laid out. Even though some of the coal cutting operations which Powell Duffryn had introduced into No. 2 Colliery were later augmented by the construction of belt conveyors where the absence of geological faulting made this feasible, the number of such "fully mechanized areas" was never large. At the end of the decade, they were still the exception to the general rule. ${ }^{18}$ Everywhere else, mining methods were too deeply entrenched and consequently too expensive even for Anglo American just to sweep them away. Instead the new management team had to make the best of a bad job by modifying what they could not change.

Supervision underground was immediately tightened up. Over the course of the two previous decades, the ratio of white supervisors to black labourers had fallen dramatically. There were at least two reasons why this had happened. Before serious faulting was encountered at the start of the $1940 \mathrm{~s}$, Wankie's relatively wide working faces had enabled white miners to keep an eye on several gangs of black workers at once, certainly more than was normal on gold mines. ${ }^{19}$ From 1941 onwards, however, "the adverse conditions met with underground [.. .] [caused]

"ZMM, File 361/1376, "Production of Coal and By-products: Wankic Coalfield". See also Report of the Directors for the year ended 31st August 1954, p. 7.

"I Ibid.

19 Phimister, "Coal, Crisis and Class Struggle", p. 122. 
the mine's producing faces to become widely distributed"..$^{20}$ In 1949 the number of working faces was already "almost too numerous to count". ${ }^{21}$ But although the number of producing coal faces was increasing rapidly, the number of white miners was actually falling as first the original Wankie Colliery Company and then Powell Duffryn tried to economize on white wages. By the time Anglo American took over, the situation had deteriorated to the stage where there were between forty and fifty producing faces in each of the ten working areas which together comprised No. 1 and No. 2 Collieries. Spread over each working area were $c$. "100 native workmen", about half of whom were "lashers" and jackhammer operators. The remainder were "pushing boys", tshovishas. All of them, that is, the 100 or so labourers in each working area, were supposedly supervised by a single white miner, helped by two black "boss boys"."22

Accustomed to Transvaal collieries where "the degree of [underground] control was significantly greater", ${ }^{23}$ Anglo American's managers brought Wankie into line with South African coal mining practice by implementing measures to reduce the enormous number of producing faces. This had the great advantage of increasing the rate of daily advance over smaller "coal getting" areas, at the same time as it facilitated supervision of work gangs. ${ }^{24}$ More white miners were also hired. For the first time in years, "boss boys" [gang foremen] were themselves closely bossed. "These whites were boers," recalled Mose Kayombo, himself a "boss boy" between 1953 and 1955. "Their treatment was very tough to a boss-boy when a load of coal didn't come out on the surface in time [...] it needed extra hard work of supervision to workers for it to be completed successfully in a day."2s For ordinary workers, especially lashers, at the receiving end of all of this, it was tougher still. White miners, unflatteringly nicknamed by the black labourers under them, regularly prowled around the coal producing faces. Siwepu (whip), sando (hammer), sabule (machete), and simbaule (poisonous insect), all made their presence felt in characteristic ways, ${ }^{26}$ but none more so than maboya (hairy one) and madonola (one who beats). Maboya, a huge man who "hit Africans whenever he visited the working place", was fond of "lifting workers with one hand and shaking them so that they would work harder", ${ }^{27}$ while madonola was

20 ZCB2/21, proof of evidence, Oertel.

21 lbid., evidence taken from Hastings.

2 lbid., proof of evidence, Martin; evidence taken from Martin and Oertel.

23 Ibid., evidence taken from Martin and Oertel.

24 Bulawayo Chronicle, 10 June 1949; and Report of the Directors for the year ended 31st August 1954, pp. 6, 7.

2s Interview with Mose Kayombo, Zambezi, 19 March 1990.

${ }^{26}$ Interviews with "Wankie" Namumbi, Lukoko, 6 February 1990; Jeremiah Lubinda, Mumbwa, 20 May 1990; and Daniel Nyambe, Mongu, 17 February 1990.

27 Interview with D. Nyambe, 17 February 1990. 
feared throughout No. 2 Colliery "because he never hesitated to strike an erring native". "Munthu mnyama minazi donola wena (I'll beat the shit out of you, you black [...])" he was notorious for shouting at black workers. ${ }^{28}$

Coercive supervision was itself only one aspect of a generalized attempt by Wankie's South African owners to re-enforce colonial production relations. From Anglo American's perspective, improved productivity in the "hand-got" sections also depended on limiting the degree of "self-regulation" enjoyed by lashers in determining the amount of work they did..$^{29}$ By initially turning the wartime shortage of white miners to their own advantage, the colliery's underground labourers had successfully established their own output norms. "Over the years [...] custom and usage [...] [caused] the working week for lashing boys to fall to four days." ${ }^{30}$ At the same time, the size of their assigned daily task dwindled dramatically. In 1944, lashers "only cared [. . .] [to move] an average of 15 to 16 [tubs] per day or say 12 tons of coal". ${ }^{31}$ Five years on, as black labour too became increasingly scarce, -underground workers had, in the eyes of management, to be "overpampered". ${ }^{32}$ "The set up is this", a senior mine official explained in 1949.

A lashing boy goes underground and must do a minimum of ten tubs per shift. That amounts to $8 \frac{1}{2}$ tons [...] The standard here is ten. Supposing you stood over that native with a whip, he certainly would not do any more if he had made up his mind not to. All they go underground to do is to get over this distasteful work as quickly as they can - say this native finishes his ten tubs at ten o'clock, he is free to leave the mine. If we tried any forceful methods he would merely give notice. ${ }^{33}$

Precluded by the shortage of labour from employing "forceful methods", both the old Wankie Colliery Company and Powell Duffryn had tried instead to manipulate the work situation by means of various bonus and piecework systems. One bonus system was reserved for gang foremen: "his first job is to get these ten tubs - our standard minimum. After that his job is to get as many more out of his lashing boys as possible. He does the running around [...] the greater the number of tubs, the greater the bonus to the boss boy." According to management,

2s Interview with Ndonati Munango, Mwenyi, 26 October 1990.

29 For this term, and further discussion in the context of the Zambian Copperbelt, see M. Burawoy, "The Hidden Abode of Underdevelopment: Labour Process and the State", Politics \& Society, 11 (1982), p. 2.

${ }^{30} \mathrm{ZCB} 2 / 1 / 1$, evidence taken from Hastings.

${ }^{31}$ H.Mss, RH 16/1/4/6, G. W. Kidd, Wankie, to P. Ibbotson, Bulawayo, 5[?] November $19+4$.

32 Bulawajo Chronicle, 14 June 1949.

${ }^{33} \mathrm{ZCB} 2 / 1 / 1$, evidence taken from Martin and Oertel.

Isid. 
this worked "very satisfactorily". ${ }^{35}$ The other system applied solely to the lashers themselves, but its results were decidedly mixed. Workers were paid " $2 / 1$ [i.e. two shillings and one penny] for ten tubs, that was the standard day's work, then a bonus of $3 \mathrm{~d}$. for every tub above that". "During my time at the Wangi Kolia [Wankie Colliery] I was employed as an underground wagon boy [trammer] and then as a lasher," declared Likomena Nyambe. "As Africans we worked under the piece rate, for the ticket fell ill if one fell ill [...] We were paid for the number of truck loads of coal we could fill and haul in a day, three pennies per truck load, but if you were sick or slow the money was lost [. . .] We sold our bodies daily, tengisa mzimba."

Although some workers had responded to this particular combination of carrot and stick in the way the colliery's management had intended they should, most black miners had not. While a minority of lashers filled anything between 25 and 30 tubs daily, the great majority of underground labourers worked at a considerably slower pace. The standard minimum of ten tubs was regularly exceeded but not by very much. By the end of the decade, when output had crept back to the 1944 level, "the average in both shafts [...] [was] 15 tubs, taking the lashing boys all in all about seven hours. They commence at 7.30 a.m. and leave off normally at 2.45 p.m." 37 Unimpressed experts from the Transvaal noted that for all that Wankie's management pronounced itself "satisfied" with this result, it represented less than 13 tons per shift. ${ }^{38}$ It was, after all, a figure well below the "sixteen to nineteen tons per day shovelled by common labourers [. . .] [whether] studied in seventeenth century France, by early Victorian contractors of English navvies, [or] [. . . ] at the dawn of the twentieth century [in America]." 39

There were several reasons why none of these bonus and piecework systems were particularly effective. As a rule, bonus systems tended to work best where the degree of control exercised by labourers over the labour process permitted them to maximize as well as minimize effort. ${ }^{40}$ On many mines in Central Africa, however, this was thwarted by company failure to provide the conditions necessary for the system's successful operation:

The allocation of workers to ends was usually dictated by the shortage of labo[u]r rather than by the amount of work involved. Workers often had no chance of completing the assigned task by the end of the shift. There were frequent shortages of equipment, such as wheelbarrows [. . .] Lashers might

3s Ibid.

${ }^{36}$ Interview with Likomena Nyambe, Kalabo, 4 May 1990.

${ }^{37} \mathrm{ZCB} 2 / 1 / 1$, evidence taken from Martin and Oertel.

34 Ibid., evidence taken from Hastings.

${ }^{39}$ D. Montgomery, The Fall of the House of Labour. The Workplace, the State, and American Labor Activism, 1865-1925 (New York, 1987), p. 58.

- Burawoy, "Hidden Abode of Underdevelopment", p. 154. 
have to wait up to four hours before their ends were checked [sic] and work could begin. From time to time the system of air cooling would stop operating, and all work had to cease. ${ }^{41}$

At Wankie, where similar conditions obtained, the only lashers for whom it made any sense to exert themselves for the duration of a nine-hour shift, were precisely those "on the 'small' high stopes where they don't have to wait for tubs [...] [and therefore] lash as many as 35 [tubs] which is about 28 tons." 42 But elsewhere in the mine, the situation was very different. Most workers had to wait for lengthy periods at the start of each shift before they could begin work. On those days when they had time, it could take over-extended white miners hours to check their districts against possible rock falls. ${ }^{43}$ It could also take up to two hours for empty tubs to return underground. "The number of tubs available was quite inadequate", the Wankie Coal Commission was told, "and the time lost by lashing boys hanging about for tubs lowered output and increased costs of production." who could "load a tub in about 20 minutes", had to put up with -frequent "derailments and other stoppages caused by the irregular haulages". In January 1950, "the turn round of tubs on No. 1 [Colliery] averaged about $2 \frac{1}{2}$ hours and on No. 2, 2 hours", necessitating considerable overtime, not least on Sundays. ${ }^{45}$

Faced with an apparently intractable problem, the old Wankie Colliery Company and Powell Duffryn had both blamed low output per manshift on what they insisted were the immutable physical and mental limitations of the colliery's black labour force. "There is one factor which I think must account for the greater part of the difference [in output per manshift between Wankie and Transvaal collieries]," observed one of Powell Duffryn's mining engineers, "and that is that the underground workman at Wankie is what is known as a tropical native, and the workmen in the Transvaal are largely not drawn from those areas [. . .] I feel there must be some inherent difference in the type of lasher used normally in the Transvaal and that working at Wankie." 46 The colliery's underground manager was blunter still. "About this turnover of lashing boys, there is a little more in it than physical incapability," he argued. "The Native, to the best of my knowledge, does not like hard work. We are importing raw unsophisticated natives [from Northern Rhodesia

"lbid., pp. 154-155.

${ }^{42}$ H.Mss, RH16/1/4/6, Kidd to Ibbotson.

" ZMM, File 361/1376, Government Mining Engineer, Bulawayo, to General Manager, Wankie Collieries Ltd, 2 August 1952.

4 Bulawayo Chronicle. 10 June 1949.

4s F114/427, Assistant Government Mining Engineer, Bulawayo, to Chief Government Mining Engineer, Salisbury, 9 February 1950. See also Todd Papers, "Notes on [...] the Wankie Strike, February 1954".

${ }^{46} \mathrm{ZCB} 2 / 1 / 1$, evidence taken from Oertel. 
and Tanganyika] who volunteer for this work. It does not take them long to discover that in spite of the high wages it is not worth it, so they leave us." 47 "The Rhodesian native", declared Wankie's long-service compound manager, "has not yet developed any sense of economic dependence on his job, and large numbers are wandering round hoping to eventually find a job fairly well paid but involving little hard work, work being something naturally opposed to his inherent kraal training and instinct." 48

This attitude of resigned helplessness contrasted sharply with Anglo American's own reaction to the same situation. As racist to its carefully polished corporate core as any of its predecessors, the Johannesburg-based conglomerate's response was none the less severely practical. In the first place, it promptly cut down on the amount of time wasted at the beginning of each shift, by deploying more white miners to carry out safety, especially "shot firing" (blasting) inspections. In the interests of "efficiency, discipline, and safety", the area for which each white miner was responsible for checking was reduced in size. ${ }^{49}$ At the same time, Anglo American attempted to reshape the organization of lashing work in its own image. Drawing on its extensive South African experience, it introduced a quite differently designed mine tub. Compared to the old tubs which were $3 \mathrm{ft}$ 9ins high, with a capacity of 0.85 tons, the new ones were $2 \mathrm{ft}$ 8ins high, each having a capacity of 1.25 tons. $^{30}$ "This new mine tub", claimed the colliery's management, "was greater in capacity and larger in area but was of considerably lower design than the older tub [...] The new tub would therefore be easier to load and easier to handle."

From August 1953 onwards, preparations for the introduction of the new tubs moved into top gear. Alterations to the height of existing haulage ropes and tipplers were pushed ahead, and by November "one particular part of No. 2 Colliery" was ready. Confident that workers had been "more than adequately "prepared' by the considerable amount of propaganda undertaken with, and through tribal representatives", Wankie's South African owners announced mid-way through the month that the new tubs would come into use the following week, on Friday 20 November. Lashers were told that they would be paid $4 d$ instead of $3 d$ per tub, "the extra payment to be made for each tub filled exactly compensating for the difference in size". This was immediately disputed by dozens of workers who had previously made a point of examining the new tubs "lying on the surface before they were commissioned",

47 Ibid., evidence taken from Martin.

4t Ibid., proof of evidence, Mr G. W. D. Kidd, 10 June 1949.

49 Interview, R. D. Hutchings, Bindura, 10 April 1990.

so ZMM, File 361/1376, "Production of Coal and By-products; Wankie Coalfield"; ZCB2/ $1 / 1$, evidence taken from Martin.

s1 Todd Papers, "Notes on [. . .] the Wankie Strike, February 1954". 
but real trouble only broke out after the first shift had gone underground "in order to try the tubs for themselves". Their suspicions were confirmed almost at once. As the realization dawned amongst those lashing gangs immediately affected by the change that they were expected to fill tubs which were nearly half as big again as the old ones for only a third more pay, angry voices were raised. And when workers discovered that the bearings of the new tubs were so stiff that they could anyway only be handled with great difficulty, their anger boiled over into strike action. More than 200 lashers in No. 2 Colliery walked off the job, demanding a shilling per tub before they would return. They were joined by "some 40 jack hammer boys and boss boys"..52

Although it soon became clear that the strike was unlikely to spread, the Southern Rhodesian Government left nothing to chance. The Minister of Native Affairs, accompanied by senior officials from his Department, flew to Wankie "for consultations on the spot". ${ }^{53}$ The colliery was "already 40,000 tons down on their production", the Cabinet heard, "and no disturbances could be contemplated which would make the position deteriorate still further." G4 Grateful to Anglo American for a "politic" decision not to pass on the latest small increase in the cost of producing coal to the Colony's consumers, ${ }^{35}$ as well as for its good offices in arranging for the Transvaal Coal Owners' Association to cover the current shortfall in Central Africa's coal supply, ${ }^{36}$ the state was quick to assure Wankie's owners "that they could count on government backing". ${ }^{57}$ Indeed, Garfield Todd's Administration, in office barely three months since Godfrey Huggins's resignation to take up the reins of the interim Federal Government before its official establishment in February 1954, was keen to demonstrate that it was as committed to the interests of big business as its predecessor. ${ }^{58}$ It consequently seized on "a suggestion by the Colliery Management [...] that the $N$ [ative] L[abour] S[upply] C[ommision], who had a number of boys on the property, might be able to persuade them to take over the work on the new tubs." 59 The general manager and the compound manager of the Supply Commission were both duly summoned

52 Paragraph, including direct quotations, based on Todd Papers, "Notes on [. . .] the Wankie Strike, February 1954"; and Todd Papers, Cabinet, minutes of a meeting, 24 November 1953.

${ }^{33}$ Todd Papers, Cabinet, minutes of a meeting, 24 November 1953.

34 Ibid.

5s Ibid., Cabinet, minutes of a meeting, 21 September 1953.

so Ibid., Cabinet, minutes of a meeting, 29 September 1953.

"I Ibid., Cabinet, minutes of a meeting, 1 December 1953.

"s Amongst others, see D. J. Murray, The Governmental System in Southern Rhodesia (Oxford, 1970), pp. 159-161; and H. Holderness, Lost Chance. Southern Rhodesia 194558 (Harare, 1985), pp. 140-141.

59 Todd Papers, Cabinet, minutes of a meeting, 24 November 1953. 
to Wankie, where they eventually succeeded in exerting enough pressure on the colliery's NLSC recruits to break the strike. By the end of the first week in December it was over, the erstwhile strikers agreeing "to give the new working conditions a trial for a fortnight, and the Management to do their best to improve the track on which the tubs ran and to carry out other pieces of reorganisation necessary to ensure smooth working."

While never wavering from a public position of support for Anglo American, the government's confidence in the South African mining house's judgement had actually been badly dented during the strike. Ministers were privately informed that despite protestations to the contrary, "it was obvious that the mine authorities had failed to condition the employees to the new operations and had neglected to ensure that the lasher boys were able to make full use of the new tubs and had the coal to load [. . . T There was no evidence of the presence of agitators." "When all these minor points were taken together", concluded the Minister of Native Affairs, "there was some justification for the attitude of the new employees." persuade Anglo American to concede, however, was the "possibility of raising the bonus for the filling of tubs a little higher than the $4 \mathrm{~d}$. which they had offered". ${ }^{62}$ But even this grudging half-promise was soon withdrawn. After the trial period of fourteen days agreed to by the strikers had not only passed off without incident, but also resulted "in a daily average [per lasher] of 20 tons as against a previous average of 13 tons with the old tubs", the colliery's management first toyed with the idea of restricting any extra payment to "those filled over the average of 20 ", and then decided against any increases at all. ${ }^{63}$ Satisfied that the new system was "proving extremely successful", and bolstered by the knowledge that "the 3rd shaft had just been opened", Anglo American declared its intention of "turning out 10,000 tons of coal a day in January". ${ }^{4}$

In the weeks which followed Anglo American's confident announcement, the introduction of new tubs to other sections of the mine went ahead steadily. By mid-January 1954 all of No. 2 and most of No. 1 Colliery had been converted to the new system. Disdaining confidential advice from several government departments that their "intelligence service was weak and [.. .] their Compound Police system in need of reorganisation", Wankie's management even refused "to keep the Native Commissioner familiar with working conditions from time to time". ${ }^{65}$

\footnotetext{
- Ibid., Cabinet, minutes of a meeting, 8 December 1953.

c1 Ibid., Cabinet, minutes of a meeting, 1 December 1953.

62 Ibid.

63 Todd Papers, "Notes on [. . . ] the Wankie Strike, February 1954".

o Todd Papers, Cabinet, minutes of a meeting, 8 December 1953.

os lbid.
} 
Instead, it relied heavily on the colliery's "tribal elders" for information. These latter were men who invariably took a cautious and conservative approach to the minor compound problems which were allowed to fall within their ambit. They were also usually careful to tell the compound manager what they thought he wanted to hear. But although still in vogue on the gold mines of the Witwatersrand and on a number of Transvaal collieries, the system of tribal representation was in fact already utterly discredited closer to home. On the Copperbelt, black miners had recently and overwhelmingly rejected so-called "elders" in a secret ballot conducted by the Northern Rhodesian Chamber of Mines itself. ${ }^{66}$ In a period when even the Southern Rhodesian Government was edging towards legislation which would recognize "Native Workers' Associations", if not yet trade unions, ${ }^{67}$ Wankie's "tribal representative medium" was increasingly detached from reality. ${ }^{68}$ At the very moment that tribal elders were informing colliery officials that "the new tub was daily becoming more popular", the great majority of Wankie's black workforce were coming to quite different conclusions. ${ }^{69}$

Uppermost in many workers' thoughts was the question of wages. Compared to the abysmal levels obtaining elsewhere in the Southern Rhodesian mining industry, Wankie's black labourers were fairly well paid. In 1953 monthly cash wages on the colliery averaged $82 s$ 8d 82 shillings and 8 pence]. Other Southern Rhodesian miners could only expect an average of $63 \mathrm{~s} 5 d$ per month. ${ }^{70}$ By Copperbelt standards, though, Wankie's workers had plenty to complain about. Late in 1952, a strike by the African Mineworkers' Union (of Northern Rhodesia) had eventually gone to arbitration and ultimately won a substantial pay increase. ${ }^{71}$ At the start of 1954, "the average money wage in Northern Rhodesian mining was more than double that paid in the mining industry of Southern Rhodesia."72

But local wages not only looked small by comparison. They were beginning to shrink in size too. Despite increases in 1948, 1951 and again in 1952, black miners' wages were no higher in real terms than they had been before the Second World War. Temporary gains were constantly eroded by inflation, and between 1949 and 1954 the cost of

6 J. Parpart, Labour and Capital on the African Copperbelt (Philadelphia, 1983), pp. 127-128.

${ }^{67}$ Todd Papers, Cabinet, minutes of a meeting, 4 March 1954. See also D. Clarke, "The Underdevelopment of African Trade Unions in Rhodesia: An Assessment of Working-class Action in Historical Perspective", unpub. paper 1974, pp. 11-12.

"Todd Papers, "Notes on [. . . ] the Wankie Strike, February 1954".

lbid.

to Annual Report of the Chief Government Mining Enginecr and Chief Inspector of Mfines, Southern Rhodesia, for the year ending 31st December 1954, p. 9.

11 E. Berger, Labour, Race and Colonial Rule. The Copperbelt from 1924 to Independence (Oxford, 1974), pp. 119-120, 123.

7 W. Barber, The Economy of British Central Africa (London, 1961), p. 233. 
living was officially calculated as having risen by 28 per cent. For African households the increase was certainly bigger ${ }^{73}$ and for most of Wankie's workers this fact of life made it essential that their basic earnings were supplemented by frequent infusions of overtime pay, especially Sunday shifts. In the recent past, they had done so by regulating the piecework system to their own satisfaction. Unwilling to work at management's pace, they none the less regularly exceeded the old basic minimum by five tubs each shift. At $3 d$ per tub, this added up to an extra $1 s 3 d$ per day. They had also been able to count on working Sunday shifts at double time during Powell Duffryn's own particular struggle to expand the colliery's output. Yet all of these sources of much-needed additional income were now being threatened by Anglo American's relentless reorganization of production. "The number of Sunday shifts worked has been reduced considerably during the past year," noted the colliery's mine manager in January 1954. "Whereas in January, 1953, on an average 4,000 Sunday shifts were worked, today the average is less than 2,000." "In the old days", he added, "the period worked was markedly less than a full shift, and by custom the native received payment for a full shift at double time. This has changed. Further, the issue of special bonuses has come under greater control, resulting in the elimination of unjustified payments."

II

For underground workers in particular, this was the last straw. Black miners coming off night shift early on the morning of 25 January clustered around a notice posted "at the shaft head at No. 1 Colliery [. . .] advising them to come out on strike on 1st February". Identical notices appeared the next morning, and still others "encouraging natives to strike" began passing from lasher to lasher "in the underground workings at No. 1 Colliery". News of a meeting to be held late on Wednesday afternoon spread by word of mouth at the same time. It was attended by hundreds of workers, most of whom "listened for a while and then moved on". Their places were immediately filled by hundreds more. They heard a succession of speakers, none of whom "were known 'trouble makers' or agitators", call for "more money". Unless this demand was met, declared one speaker, identified by the mine authorities only as "Michael, a Mulala [Ila] native", "there would

${ }^{3}$ In the absence of precise figures before 1960, the post-1945 movement of real wages is much debated; see, variously, Barber, Economy of British Central Africa, pp. 218227; G. Arrighi, "The Development of Capitalism in Rhodesia", unpub. paper, n.d., passim; and A. Irvine, The Balance of Payments of Rhodesia and Nyasaland 1945-1954 (London, 1959), pp. 625-629. See also, Todd Papers, "Notes on [. . .] the Wankie Strike, February 1954".

74 Todd Papers, "Notes on [. . . ] the Wankie Strike, February 1954". 
be a strike of all workers on 1st February, next Monday [. . .] which everyone should support [...] 'Measures' would be taken to see that none of the leaders were molested in any way and if they were, there was to be retribution. Provided no violence was offered by the Europeans, no violence would be resorted to by the natives."75

Similar meetings were held on each of the following three days. All of them took place in No. 1 compound, and all of them shared what the management sourly called "a 'migratory' characteristic". Word of the impending strike was being carried to every corner of the colliery. Indeed, the effect of this "two-legged propoganda [sic] spread from previous gatherings" ensured huge turn-outs at successive meetings on Saturday afternoon and Sunday morning, when most workers were free to attend. Crowds of over 3,000 people cheered "Michael" on as he demanded "more money". Specifically, this meant "a $3 /$ - increase per shift worked; increments to be increased from 5/- to 7/6; an end to 'maxima' in grades and categories of pay; and cash instead of rations". A message conveyed by "a Senior Police boy" to the effect that the Compound Manager was "in his office and prepared to meet a delegation", was rejected on the grounds that "delegates would be victimised". This suspicion was doubtless well-founded, as strikes were illegal under the Master and Servants Ordinance. Instead, the meeting determined to mobilize as many people as possible in support of strike action, and on Sunday evening "a series of meetings were held in No. 2 Compound [...] [These] were addressed by certain of the agitators from No. 1 Compound, and representatives from No. 3 Compound were present." 76

Speakers in favour of striking work the next day were generally well received. While initial support for strike action had come overwhelmingly from lashers and gang foremen ("boss boys"), many of whom feared that the new work regime would result in their pay packets shrinking dramatically unless they worked themselves to the bone, they were subsequently joined by thousands of workers in other job categories. Underground labourers as a whole were unhappy with their rudimentary and usually dangerous working conditions. About six months before Anglo American assumed control of the colliery, Powell Duffryn's Wankie management had been told by government inspectors to do something about the "utter lack of sanitation and hygiene arrangements in the underground sections". "The smell of human faeces is evident in many parts of the underground workings and the lack of proper facilities is responsible for this," insisted an official letter to the general manager. "The old workings are being extensively used and if some

75 Ibid.

7bid.

$"$ Ibid., Annexure "A", List of leaders and speakers in February 1954 strike. 
serious consideration is not given to the subject; especially as tropical natives are employed and hot humid conditions prevailing, the danger of hookworm spreading will add further to your already large amount of man-hours lost through accidents and sickness."78 But this elementary advice had simply been ignored by both Powell Duffryn and Anglo American. As far as the latter was concerned, the "requirements of the development programme" came first. ${ }^{79}$ Hookworm and other parasitic diseases, already carried by at least 50 per cent of new arrivals from north of the Zambezi, assumed "epidemic" proportions as they began to infect "long-service boys". By the time of the strike, hygienic conditions underground were "nothing less than shocking". A subdued Cabinet later agreed that "there could be no justification whatever for the Company's lack of interest". ${ }^{80}$

Nor was Wankie's South African management particularly interested in mine safety. Although Anglo American lost no time in "fixing up" the mess left behind by Powell Duffryn, ${ }^{81}$ it did so in the explicit context of trying to increase the colliery's output. ${ }^{82}$ While the closer inspection by a bigger number of white miners of blasting operations caused the number of fatal accidents to decline after 1954, the company's initial concern had been less with the accident rate per se, than with finding a more efficient means at the start of each shift of discharging its legal obligations under the safety regulations of the Mines and Minerals Act. ${ }^{83}$ Other safety measures, by comparison, were cursorily enforced and extremely rough-and-ready in practice. "The high hanging [roof] was very dangerous and virtually impossible to examine properly," remembered one white miner. "We carried wooden poles to test whether the roof made a 'drumming' sound [. . . ] if it did, it was about to fall." Encouraged by a bonus system which placed a premium on speed while penalizing caution, this casual attitude resulted in "extremely dangerous mining": "because of piecework, no-one would stop to check the hanging wall". 85 "Three times in a week there were casualties and deaths", recalled a former "boss boy". ${ }^{86}$ "Nearly every day there were

7 ZMM, File 361/1376, Government Mining Engineer, Bulawayo, to General Manager, Wankie Collieries Ltd, 2 August 1952.

77 Todd Papers, "Notes on [. . .] the Wankie Strike, February 1954".

\$ Ibid. Cabinet, minutes of a meeting, 29 March 1954. See also ZCB2/2/1, evidence taken from Kidd; and from Major P. J. Kenworth, Salisbury, 8 June 1949.

"Interview with A. G. Koen, 18 August 1986.

"Todd Papers, "Notes on [...] the Wankie Strike, February 1954". For a classic account of company attitudes towards mine safety on the Rand in this period, sec H. J. Simons, "Death in South African Mines", Africa South in Exile, 5 (1961).

w Wankie Colliery Company Ltd, Report of the Directors for the year ended 31st August 1957 , p. 8.

* Interview with R. D. Hutchings, 10 April 1990. A metal pole used against rock might have caused a spark, igniting the methane gas always more or less present in coal mines. soid.

so Interview with M. Kayombo, 19 March 1990. 
rockfalls leading to injuries and deaths", said Daniel Nyambe, a "timber boy" on the colliery in the early 1950s. "Africans mainly suffered because they were the ones actually involved in labour [... .] When we went on strike we wanted higher pay, [but] many [also] felt that the whites were killing them deliberately." 87

But if underground workers had reasons enough of their own to contemplate strike action, they also harboured grievances which affected everyone regardless of whether they worked below or above ground. Most black miners were thoroughly fed up with their run-down and overcrowded living quarters. By the beginning of 1954, Wankie's mine compounds, covering a combined area of over 250 acres, contained an estimated 17,500 men, women and children. ${ }^{8 s}$ The number of black workers at the colliery had been growing by about a thousand or so each year since the second half of 1949 when the first of several programmes to expand production had been initiated. During 1950 the total figure climbed from 5,666 in January to 6,789 in December, and by the end of 1951 Wankie was employing 7,912 black labourers. Eighteen months later it had more than 9,500 Africans on its books. ${ }^{89}$ Yet this rapid increase in the size of Wankie's black labour force had not been accompanied by anything like a commensurate increase in the size of its housing stock. Like the old Wankie Colliery Company before them, both Powell Duffryn and Anglo American had expressly subordinated the provision of welfare to the expansion of production. Workers' housing was a long way down their list of priorities. "Due to the large increase in the [black] labour strength, necessary to meet the increased demand for coal," explained Anglo American, "no headway has been made in overcoming the overcrowding problem."

As a result of deliberate neglect, the colliery's compounds on the eve of the strike comprised an unsightly mixture of dilapidated barracks or "hostels", corrugated iron kaytor huts, "temporary" pole and dagga buildings, and a smattering of "superior" houses specially built for a limited number of relatively senior married employees. First introduced towards the end of the 1920s, this particular building scheme had foundered initially on the Depression, and latterly on the urgent priority accorded to meeting the capital cost of mechanization. Such surplus cash as occasionally turned up tended to go into building houses for white artisans, leaving only derisory sums for black accommodation. In

Interview with D. Nyambe, 17 February 1990. See also, interviews with W. Namumbi, 6 February 1990; and G. Mulemba, 8 August 1990.

ZCB2/11, proof of evidence, Kidd; and Annual Report of the Chief Government Mining Engineer and Chief Inspector of Mines, Southern Rhodesia, for the year ending 31st December 1953, p. 34.

29MM, File 361/1376, Chief Surveyor to Chief Government Mining Engineer, 4 May 1950 and attached correspondence.

To Todd Papers, "Notes on [. . . ] the Wankie Strike, February 1954". 
1953, while "the European housing programme was pressed forward with all speed [...] and as many as 12 houses were completed per month," " the construction of African accommodation languished. The few houses that were grudgingly built were hopelessly inadequate: "just a room and kitchen and porch". ${ }^{22}$ They did not begin to meet the needs of married workers, whose families slept six and seven in a room, ${ }^{93}$ but even they were infinitely preferable to the sordid conditions endured by single labourers. "We were cramped in crowded rooms with open lavatories, not less than 20 people were heaped in a room", one worker said." "The sibonda se njini was responsible for order in the room, [. . .] [but] some occupants stole from the others [. . .] drunkards, thieves, people of varied characters were made to live together."9s

Many black workers were also increasingly irritated by Anglo American's paternalistic insistence on rations rather than cash. Although the colliery's owners were adamant that "having regard to the type of labour employed and the conditions prevailing at Wankie [...] the Company policy is correct and the demand made by the Natives in this regard should not be acceded", $\%$ other industrial concerns had begun to change their ways. In December 1953 several large Bulawayo firms agreed to pay workers cash in lieu of rations, and news of this concession was not long in reaching Wankie. ${ }^{97}$ For labourers pinched by the rising cost of living, and squeezed by Anglo American's determination to end what it perceived as "abuses" of the bonus system, the prospect of extra cash from any source was attractive. Not everyone agreed, of course, and some miners were reluctant to forgo the convenience of drawing rations directly from the Company. ${ }^{98}$ But what tipped the balance in the opinion of many compound dwellers was precisely the difficulty which more and more people encountered in trying to obtain their fair share. According to Sayela Mulemba, "the problem was uneven distribution of food rations, so the people demanded money to buy food for themselves".99 "There were times when the men came back from work and found that all the rations had been shared," recalled Ma-Nyambe Sitali, who had gone to live with her husband at "Wangi Kolia" in June 1952. "The officials could have dished out

${ }^{91}$ Annual Report of the Chief Government Mining Engineer [. . .] for [. . .] 1953, p. 34.

22 ZCB2/1/1, evidence taken from Kidd.

${ }^{93}$ Interviews with M. Kayombo, 19 March 1990; A. Kwibisa, Lusaka, 6 April 1990; and K. Mbombi, Mbenga, 22 January 1990.

Interview with G. Mulemba, 8 August 1990.

95 Interview with D. Nyambe, 17 February 1990.

* Todd Papers, "Notes on [. . .] the Wankie Strike, February 1954".

7 Ibid.

98 Interview with M. Kayombo, 19 March 1990.

99 Interview with S. Mulemba, Mumbwa, 2 March 1991. 
enough food, but some unscrupulous ones cheated on these rations [. . . ] so we called for money." 100

Despite the fact that these grievances, especially "the cry for more money", were repeatedly voiced at all three meetings held over the weekend immediately before the strike, the colliery's management refused to believe that the call for action enjoyed widespread support. ${ }^{102}$ While information gathered by the mine authorities claimed that waverers were whipped into line by assaults and death threats, and later kept in place by particularly robust picketing, ${ }^{102}$ such other evidence as there is suggests that support for the strike not only stretched across different job categories but also across lines of ethnicity and gender. For most of Wankie's history, its black labour force had been drawn very largely from north of the Zambezi. Statistics collected in 1950 revealed that about 4,000 out of a total of c. 6,500 workers were from Northern Rhodesia. Other Central African sources, including Angola and Tanganyika, supplied a little under 1,000 men. About 450 labourers came from Nyasaland, and less than 100 from Mozambique, while Southern Rhodesian Africans comprised only some 12 per cent of the labour force. ${ }^{103}$ But for all that Native Department officials busily calculated that these broad divisions could be broken down further into "no less than 38 tribal groups present at the Colliery", ${ }^{104}$ the workers themselves completely ignored the so-called "tribal representatives" foisted on them by Anglo American: "no complaints or claims were put forward through them". ${ }^{105}$ Nor did a list of strike leaders subsequently compiled by the British South Africa Police point to any significant ethnic dimension to the strike. On the contrary, it underscored the extent to which the strike was led by long-service, relatively skilled workers, particularly "boss boys" who numbered seven out of the twenty-three "leaders and speakers", and short-term, usually unskilled labourers alike. ${ }^{106}$

Predictably, all of them were men. But if the strike leadership was exclusively male, rank-and-file support was not. On the colliery's own reckoning, c. 40 per cent of its black labour force was attempting to lead some kind of settled family existence. Thousands of women lived more or less permanently with husbands or lovers in Wankie's sprawling compounds. ${ }^{107}$ "Wives" whose "daily tasks included preparing meals for

\footnotetext{
${ }^{100}$ Interview with M.-N. Sitali, Mumbwa, 9 February 1991.

${ }^{101}$ Todd Papers, "Notes on [. . . ] the Wankie Strike, February 1954".

102 lbid.

${ }^{103}$ ZMIM, File 361/1376, "Wankie Colliery Statisties: March 1950".

104 Outpost, April 1954, p. 12.

10s Todd Papers, "Notes on [.. . ] the Wankie Strike, February 1954".

106 lbid.

10 $\mathrm{ZCB} 2 / 1 / 1$, evidence taken from Kidd.
} 
[their] husband, cleaning the house and washing their husband's job clothes e.g. overalls, trousers, boots and the hard hat, impahla $e$ mgodini", also attended twice-weekly classes in "housecraft and childkeeping" organized by "the office of the Compound Manager". ${ }^{108}$ "As a woman I benefited a lot", admitted Ma-Nyambe Sitali. "I learnt better ways of cooking and things like knitting socks and mending clothes. Women who did well in these courses such as Bo Manjekwa, Mrs Nalishebo Sikweti and others I cannot remember now were rewarded with sewing machines and money." "We were also encouraged by the Compound [manager] to take our children below the age of five regularly to the clinic for check-ups and weighing", acknowledged Saela Mulemba. "As a result of this I never lost one of my 13 children."110

For some women, these newly-acquired skills opened up the prospect of financial independence, and for this reason and doubtless others as well, not all of them were prepared to denounce the colliery's compound management. "Women who tried to dodge the protest were forced under the pain of a beating to join [...] Bo Manjekwa was almost beaten for refusing at first." "For the majority of women, though, courses in "better" housekeeping and childrearing seemingly served to reinforce gender roles, while simultaneously strengthening the form of patriarchy under construction in compound society. Authority lost by male elders in the countryside was differently reconstituted in male heads of mine households. Although the evidence is patchy in the extreme it does provide one or two glimpses of the compound's female inhabitants being mobilized, initially at least, through channels of male control. ${ }^{112}$ "We were all urged by the men to march on the offices of the Compound Manager", recalled one miner's wife. ${ }^{113}$ "Our menfolk led the way", said another. ${ }^{114}$ Yet once mobilized, most women made it clear that the grinding realities of compound life affected them as much if not more than they affected men. "As the [food] shortages became worse, there grew out a wide cry [...] Lozi women and other women from other tribes joined their men in demanding money."11s One of the most noticeable aspects of the strike, observed

\footnotetext{
108 Interview with M.-N. Sitali, 9 February 1991.

100 Ibid.

110 Interview with S. Mulemba, 2 March 1991.

111 Interview with M.-N. Sitali, 9 February 1991.
}

112 For further discussion, see, variously, G. Chauncy, "The Locus of Reproduction: Women's Labour in the Zambian Copperbelt, 1927-1953", Journal of Southern African Studies, 7, 2 (1981); J. Parpart, "The Household and the Mine Shaft: Gender and Class Struggles on the Zambian Copperbelt, 1926-64", Journal of Southern African Studies, 13, 1 (1986); and E. Schmidt, "Negotiated Spaces and Contested Terrain: Men, Women and the Law in Colonial Zimbabwe, 1890-1939", Journal of Southern African Studies, 16, 4 (1990).

"II Interview with S. Mulemba, 2 March 1991.

it Interview with M.-N. Sitali, 9 February 1991.

113 lbid. 
a senior police officer, "was the large number of women and children integrated in the huge crowds". 11

The upshot of all of this was a "total strike [which] became effective on the morning of Monday 1st February". It included not only miners but also domestic workers and shop assistants. "The only natives working", reported Anglo American, were

i) those employed in the hospital; ii) those employed by the Railways and Government; iii) those employed at the Zambesi pumping station who had had no contact with the agitators; iv) the employees of two contractors who were later on Monday morning intimidated into strike action; v) 20 or so loyal mine employees at No. 2 Colliery; [and] vi) the employees of a trader who operated Eating Houses (food stores) in the No. 1 and No. 2 Compounds. ${ }^{17}$

While strike leaders busied themselves with shoring up the miners' solidarity at "meetings held in No. 1 and No. 2 Compounds contemporaneously", government officials on the spot soon discovered that Anglo American was in no mood to negotiate either. According to a colliery company report on the strike, when the local Native Commissioner advised the strikers that their action "was illegal, that a delegation should be appointed and that there should be a return to work", the reply was that "only if the Management would attend the meeting and agree to the demands made, would the strikers return to work". "The management was strongly pressed by the Native Commissioner to visit the meeting and to negotiate", added the report, "but, with the agreement of the Consulting Engineers of the Company, the Management refused to do this since it was irregular and might have compromised the Company if proper negotiations could be established."118

Unimpressed by Anglo American's sense of what was proper, the Southern Rhodesian Government was watching the unfolding events at Wankie with mounting alarm. Initially worried that the Northern Rhodesian African National Congress might be behind the strike, and recalling that Alfred Simarika, the Congress Secretary, had threatened to halt Federation in its tracks by telling "every Northern Rhodesian native to cease work and walk home", Todd's Administration decided to act. ${ }^{119}$ As stocks of mined coal were "sufficient only for a few days" consumption, a quick return to work was needed [. . .] moreover, it was felt that serious labour unrest would affect the new Federal Government's ability to raise loans on the London Market." ${ }^{20}$ The

"16 Outpost, April 1954, p. 13.

"1" Todd Papers, "Notes on [... ] the Wankie Strike, February 1954".

is Ibid.

${ }^{119}$ F248, Federal Defence, Standing Ministerial Committee on Security: Wankie Strike:

Police Review (confidential). Note by the Secretary, n.d. (March 1954).

120 J. Wood, The Welensky Papers. A History of the Federation of Rhodesia and Nyasaland (Durban, 1983), p. 404. 
government "immediately invoked its new Peace Preservation Amendment Act which gave the police wide powers to restore order, including imposing curfews and searching without warrants."121 Rhodesia Railways were instructed to "cut their goods trains by more than half in order to conserve their limited stocks of coal and so ensure the maintenance of essential services". ${ }^{122}$ Steps were also taken to bring the Northern Rhodesian Chamber of Mines, concerned by the fact that there was less than seven days' supply of coal on the Copperbelt, fully into the picture; ${ }^{123}$ and most dramatically of all, Todd himself, accompanied by the Minister of Native Affairs, flew to Wankie to take personal control of the situation. "The Southern Rhodesian Government", announced Todd, "was determined to go on producing coal at Wankie with whatever labour was available, and was not prepared to have Wankie close down because of an illegal strike."124

On their arrival at the colliery on Tuesday morning, the Prime Minister and his entourage were promptly briefed on the latest developments. An output of about 2,400 tons per day was being produced from the mechanized sections of No. 2 shaft by a skeleton staff of white miners, and arrangements had been made to bring in further "European" workers from other mines in the colony. These eventually totalled "about $170 \mathrm{men}$, and it was expected that with them, the colliery would be able to raise about 4,000 tons of coal a day, [... .] enough to meet essential needs."125 At the same time, the Copperbelt was asked to stand ready "to find 400 European volunteers to work at Wankie". ${ }^{126}$ As always, the state and the mining companies could safely rely on the racial division of labour to fragment working-class solidarity. Organized in their own Associated Mineworkers of Rhodesia, white miners feared and despised black workers for whom trade union activity was illegal in settler-ruled Southern Rhodesia, if not in the North under the relatively mild dispensation of the Colonial Office. ${ }^{127}$

The strikers themselves were refusing all mine rations, and had ordered stores in the compounds to close. They were feeding themselves by "picking many of the mealies [maize] they planted some months ago and which were now ripening". ${ }^{128}$ Earlier in the day, a noisy protest by hundreds of women outside the Compound Manager's office had gone off peacefully, ${ }^{129}$ but the arrest of twenty-six pickets at No. 2

121 Ibid.

122 Bulawayo Chronicle, 5 February 1954.

${ }^{123}$ Rhodesia Herald, 2 February 1954.

124 lbid., 4 February 1954.

125 lbid., 2 February 1954; ibid., 4 February 1954.

126 Jbid., 3 February 1954.

'27 For further discussion, see 1. Phimister, "White Miners in Historical Perspective: Southern Rhodesia, 1890-1953", Journal of Southern African Studies, 3 (1977).

${ }^{128}$ Rhodesia Herald, 4 February 1954.

${ }^{129}$ Interview with S. Mulemba, 2 March 1991. 
Colliery shortly afterwards had almost precipitated a major clash between strikers and police. "Immediately after the arrest, 5,000 Natives from No. 2 Colliery started a march on the township and Magistrate's office", recounted a government statement issued once the strike was over. "Between the two collieries they were diverted by a very commendable action on the part of Captain Brewer [officer commanding the B.S.A. Police]. They were diverted to the football field at No. 1 Colliery, where they joined the great masses that were assembling there." 130 "The Native Commissioner and Captain Brewer", it was later explained,

then had a hasty conference, and proceeded to meet the congregation at the football field. The Native Commissioner opened his remarks by telling the mass that certain pickets had been arrested and lodged in the cells at the police station, but, as the strikers had behaved themselves so well otherwise, he had decided to release the pickets. He again warned them that picketing would not be allowed. This wise action had a very favourable reception from the vast majority of the concourse [...] The pickets were thereupon released at No. 2 Colliery. ${ }^{13 \mathrm{t}}$

Brewer's quick thinking had been prompted by the unpalatable knowledge that he had barely 100 policemen at his disposal. Police reinforcements were on their way from Salisbury, as well as from Northern Rhodesia, but neither contingent was expected to reach the colliery before Wednesday. In these circumstances, prudence had dictated retreat in the face of the huge crowd of strikers. But although Brewer's superior officers hastened to assure their distinguished audience that everything was now "under control and the limited production was not being hampered", the Prime Minister would have none of it. ${ }^{132} \mathrm{He}$ insisted on mobilizing members of the Southern Rhodesian Territorial Force. All in all, four companies of white reservists, plus two armoured cars, were ordered to Wankie, and a further company of the Rhodesian African Rifles held in reserve at Bulawayo. This meant that "when all the Territorial troops had arrived, the security forces [including police] at the Collieries would number 710". ${ }^{133}$ "We took [. . . [ [this] decision", Todd subsequently informed the Legislative Assembly, because "every able-bodied European man, not only on the mines but on the Railways and the various contractors' gangs around Wankie, was down the pits. Even the clerks had left their desks and gone down the pits and the women and children were left really, you might say without any European males on the surface, and the position was a dangerous one."13 "The position", pronounced the Minister of Native Affairs,

\footnotetext{
130 Rhodesia Herald, 9 February 1954.

${ }^{231}$ Ibid.

132 Wood, Welensky Papers, p. 404.

133 Rhodesia Herald, 4 February 1954.

'34 Southern Rhodesia Legislative Assembly Debates, 5 May 1954, col. 811.
} 
"was that there were some 16,000 natives involved, and the No. 1 Colliery compound is right up against the European suburb. The mass of these natives are more primitive than the labour force in any other part of Southern Rhodesia in that they come from the backwoods of the north. In that number there must be some liable to do anything in a state of excitement. There are epileptics and all kinds and conditions of nature there."135

Having demonstrated his "decisiveness and lack of inhibition in calling out [the] Territorial Army", ${ }^{136}$ to the general satisfaction of the settler electorate, Todd hurried back to Salisbury and the celebrations surrounding the opening of the Federal Parliament. But for all its public posturing, the Southern Rhodesian Government was keen to resolve the dispute speedily and, if at all possible, peacefully. Ministers readily conceded that "during the whole of the strike we had at the back of our minds the need for coal production". ${ }^{137}$ Privately dismissive of Anglo American's disingenuous claim that "the agitators had no substantial grievances or complaints", ${ }^{138}$ the senior government officials remaining at Wankie after the Prime Minister had left tried repeatedly to open discussions with the strikers. This was not easy. Strike leaders were no more willing to identify themselves at this stage than they had been previously and attempts to negotiate with the strikers late on Tuesday afternoon, during the whole of Wednesday, and again on Thursday morning, all came to nothing. On each occasion, "most of the strikers [...] indicated that they were not prepared to go back to work until their demands were met". ${ }^{139}$ Even if not intended to be taken literally, the message from "several big meetings" called by the striking miners themselves was always the same: "they would stay in their compounds for seven days and would not have any discussions with Europeans during that time". ${ }^{140}$ The silence which followed a speech by the Native Commissioner early on Thursday morning was broken by the blowing of whistles and shouts of "mali kupela (money only), mali kupela": "amid cheering and shouting, half of them [out of a crowd of c. 2,000] moved off to the compound to get their situpas [passes]. They wanted to be signed off, they said, if they did not get their 'rise' immediately. Mali kupela."141

From that point onwards, however, the strikers' resolve began to weaken, although earlier signs of dissension in their ranks had been

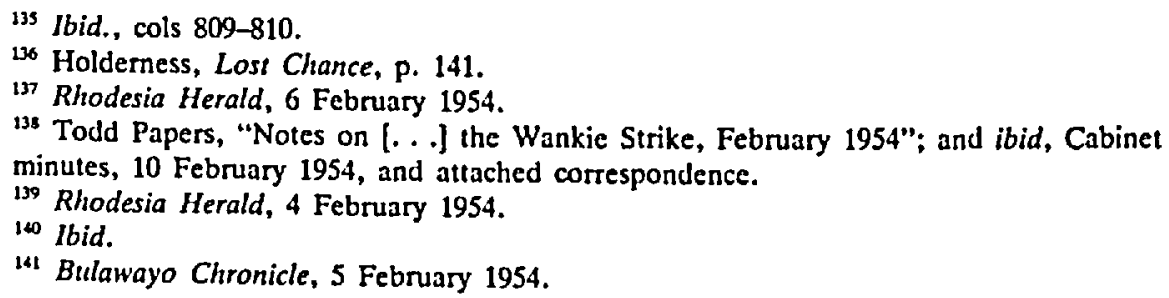


easily enough contained. At one of Tuesday's meetings, a lone voice advocating an unconditional return to work had been abruptly silenced by a barrage of blows and kicks, and the potentially unsettling effect on the strikers" morale of the action by "a group of 60 workers, most of them recruited from Nyasaland [...] [who] went to the mine administration on Wednesday morning and stated they were not interested in the strike and wanted to be signed off", had been offset later in the day by a huge demonstration at which thousands of miners "threw their tickets [contracts] into a 44-gallon drum", by way of symbolizing their rejection of the colliery company. ${ }^{152}$ But not much could be done about the fact that the strikers were running out of food. Since the closure of the compound stores on Monday, "some Natives had been going as far as Dett, about 30 miles from Wankie, to buy food", but this was not a realistic option for the vast majority of people. ${ }^{143}$ Nor could the miners' "mealie patches" [maize gardens] sustain them for very long. And while Todd was undoubtedly premature in claiming on Wednesday morning that "some of the Africans are getting weary and hungry and are beginning to worry about their pay", ${ }^{144}$ many of them were certainly worried a day or two later by the growing military force arrayed against them. "The whites came with soldiers and armoured cars", remembered one black striker. "They threatened to shoot us all."14s

For its part, Todd's Administration was now ready to push matters to a conclusion. With the military build-up complete, the compounds could be extensively patrolled on a 24-hour basis "by groups comprising three to four Europeans and six African Constables operating with radio vehicles." 146 Soldiers seemed to be everywhere. Strikers invariably gathered under the unblinking gaze of armed men. During Thursday morning's meeting, for example, "a company of the 2nd Battalion, The Royal Rhodesia Regiment, armed with rifles, and B.S.A. Police riot squads stood by. The police included a detachment of African constables, who were steel-helmeted, and carried shields and batons." ${ }^{147}$ Satisfied that it had the means to enforce an end to the strike, the government issued an ultimatum late on Thursday afternoon. A huge crowd of more than 5,000 men and women, "standing on the hill which slopes away from the [No. 1 compound] offices and into the location", ${ }^{148}$ heard the local Native Commissioner deliver a message from the Minister of

\footnotetext{
142 Rhodesia Herald, 4 February 1954; ibid., 6 February 1954; ibid., 9 February 1954.

i43 Ibid., 5 February 1954.

144 Ibid., 4 February 1954.

Iss Interview with K. Mbombi, 22 January 1990.

its Ouppost, April 1954, p. 13.

147 Bulawajo Chronicle, 5 February 1954.

iss Ibid.
} 
Native Affairs. Speaking through a police loudhailer, the Native Commissioner told the crowd that

these are the final words of the Government. They will not tolerate an illegal strike. You have behaved yourselves and nobody has been hurt [...] The police and military are here to protect everybody, and are your friends as long as you behave yourselves. Any disturbances will be severely dealt with. The Government has decided to send five or six Europeans from Bulawayo [...] This labour board will deal with your troubles. They will come here to listen to your complaints, and when they go back they will report on your complaints to the Government. You can appoint your committees or deputations to speak to these men. These men will be here within the next 14 days. It will be best for you now to go back to work, and the police will protect you. Those who do not wish to work will be signed off, and must leave the district immediately [. . . I I want to make this quite clear: those who want to work may do so and nobody will interfere. Those who do not want to work will come here at 6.30 and will be signed off. That is all. Think on this thing - this is a big thing come back tomorrow with your decision. ${ }^{1+9}$

The strikers reacted to what they had just heard with a mixture of apprehension and defiance. No sooner had the Native Commissioner finished speaking than "the military appeared on the scene [...] to stage a well-timed flag march"..$^{50}$ Some workers decided there and then that for them the strike was over, and several hundred miners indicated their willingness to return to work immediately. Most of the others, presumably those who had constantly interrupted the Native Commissioner's speech with "cries and catcalls", were less readily intimidated, however. But even as they slowly moved back to their compounds, many of them "shaking their heads", it was clear to the watching officials that "the mob was now disorganised and there was an indication of a general softening". ${ }^{51}$ Just before the meeting, the strike leaders had been forced to climb down over the closure of the various stores in No. 1 and No. 2 compounds, and request that they be reopened. ${ }^{152}$ Almost everyone had run out of food, and by Friday morning, 5 February, "a 'drift' back to work had started, resulting largely from the fact that the strikers were starting to get hungry". ${ }^{133}$ The minds of those who were still undecided were concentrated by a police sweep through the colliery "in which all strikers who asked to be signed off were removed from the compounds to an assembly point on the railway line, from where they would be sent by special train to Northern Rhodesia". ${ }^{154}$ In the event, only c. 300 workers took the train north,

\footnotetext{
${ }^{149}$ Rhodesia Herald, 9 February 1954.

iso Outpost, April 1954, p. 13.

is! Bulawayo Chronicle, 5 February 1954.

152 Ibid.

133 Todd Papers, "Notes on [. . .] the Wankic Sirike, February 1954".

1s4 Rhodesia Herald, 6 February 1954.
} 
compared to the thousands who sullenly agreed that the strike was over. ${ }^{15 s}$ Their temper was hardly improved by the arrest of four strike "ringleaders", but the police, "acting on certain information received", had accurately gauged the strikers' mood and the arrests "were made without a murmur from the surrounding natives". ${ }^{156}$ "The situation at Wankie this week-end has been almost normal", reported the Rhodesia Herald. "The special shift worked on Sunday was considered to serve the double purpose of increasing production and keeping the Africans occupied at a time when the strike has not entirely left their minds. It is confidently expected, though, that they will now wait quietly for the Board of Inquiry to be set up."157

\section{III}

But Wankie's black miners were far from finished. Forced back to work, they proceeded to stage a two-month "go-slow", initially for the duration of the Labour Board's deliberations, and eventually until Anglo American agreed to implement the recommended wage increases. In exerting pressure on their normally unyielding South African employer, the colliery's labourers were greatly helped by a stroke of luck. Early in March "a most serious state of mining conditions suddenly presented itself in an area of No. 2 Colliery, where all working faces encountered faulting. Owing to the dangerous ground almost the whole of available faces had to be temporarily abandoned." 158 This "unexpected difficulty", reported the chairman of the colliery company, "occurred at a most inopportune moment when we were in the throes of completing the remodelling and reorganisation of the underground layout and mining operations at No. 1 Colliery", with the net result that coal production plunged. ${ }^{139}$ Nor could any relief be anticipated from No. 3 Colliery. Embarrassed company executives explained that "the new Colliery had been expected to be producing in April but owing to lack of artisans it was not expected now that production on any reasonably large scale would start until about the end of June"..$^{160}$ By the beginning of April, the coal shortage was already "severe", and four weeks later it was "highly probable that the Union [of South Africa] Government would

\footnotetext{
1ss Ibid., 8 February 1954.

iso Outpost, April 1954, p. 14; and Rhodesia Herald, 9 February 1954.

157 Rhodesia Herald, 8 February 1954.

138 S[outh] A[frican] S[tate] A[rchives] P[retoria], HEN710 vol. 12, High Commissioner, Salisbury, to Secretary for External Affairs, Pretoria, 10 May 1954, and altached correspondence.

130 Wankie Colliery Company Lid, Report of the Directors for the year ended 31st Alugust 1954. p. 6. See also, Southern Rhodesia Legislanive Assembly Debates, 5 Mlay 1954, cols $772 \rightarrow 774$.

in Rhodesia Herald, 4 May 1954.
} 
again be approached to render assistance by supplying more coal to Central Africa". "I am told by the Southern Rhodesia Minister of Mines", wrote the South African High Commissioner in Salisbury, "that the difficulties being experienced at Wankie will have serious repercussions on the Central African economy and that for some months to come the situation will be grave." 161

Fully aware of the pressing need to restore the colliery's "African labour force to full efficiency", ${ }^{162}$ the four members of the Wankie Regional Native Labour Board sweated to produce a report at short order. Its recommended across-the-board pay increase of five shillings per month was well below the strikers' more unrealistic demands, but was none the less welcomed by the colliery's black workers. ${ }^{163}$ The Board also condemned the poor state of Wankie's African housing and hospital facilities, remarking in passing that "it seemed to be inexplicable how the health authorities had failed to enforce their recommendations in the past". ${ }^{164}$ It was particularly critical of the breakdown in communication between management and labour both before and during the strike and suggested that thought should be given either to extending any proposed recognition of African labour organizations to the mining industry, or, at the very least, ways of improving Wankie's system of "tribal representation" should be found. Agreeing that it needed to establish "good industrial relations and provide a willing and productive labour-force", the Cabinet began re-drafting its proposed Native Industrial Workers Union Bill along the lines suggested, Todd himself having publicly announced some weeks previously that "it was time to reconsider the recognition of the African trade unions". ${ }^{165}$

None of this appealed very much to the Anglo American Corporation, but having been obliged by force of geological circumstance to fall back on labour intensive methods of "hand-loading" in order to keep output from dropping further, it finally gave way and raised the wages of its black workforce on 14 April. ${ }^{166}$ Insisting at every opportunity that "no wage award should have been recommended by the [...] Board or approved by the Government", ${ }^{167}$ the Corporation resolved to dig in its heels and, indeed, claw back whatever it could. It began by persuading the Cabinet that "as the Company had expensive plans in hand for

161 SASAP, HEN710 vol. 12, High Commissioner to Secretary for External Affairs.

162 ZMM, File 361/1377, Chief Government Mining Engineer, Salisbury, to the Secretary, National Native Labour Board, 19 March 1954.

${ }_{163}$ Southern Rhodesia Legislative Assembly Debases, 28 April 1954, col. 395.

164 Todd Papers, Cabinet minutes, 29 March 1954.

16s Wood, Welensky Papers, p. 404. See especially, Report of the Select Committee on the Subject of the Native Industrial Workers' Union Bill, March, 1956, passim; and Clarke, "Underdevelopment of African Trade Unions in Rhodesia", p. 11.

${ }^{166}$ Southern Rhodesia Legislative Assembly Debates, 5 May 1954, col. 772.

167 Todd Papers, "Notes on [... .] the Wankie Strike, February 1954". 
improving conditions in the industry", the Labour Board's report should not be published, not least because "publication might lead to necessarily adverse comment overseas". ${ }^{168}$ This small success was soon afterwards followed by the blunt announcement that "having regard to all the misfortunes which have fallen on the Colliery during the last financial year", the average selling price of coal was being raised immediately "by one shilling per ton, making the figure 19/3d per ton at the pits-mouth". ${ }^{169}$ At much the same time, Anglo American's friends started lobbying the government for permission "to staff No. 3 Colliery with indentured Nyasaland natives". "The Colliery's reasons", the Cabinet was discreetly informed, "were that they thought indentured labour would be more reliable in times of trouble and could be called upon to keep essential services going." 170 And in case there was any doubt about the lessons it had learnt from the strike, Anglo American also began marshalling its formidable resources to counter any suggestion that official recognition should be extended to a black miners' union. "The superimposition of Native Industrial Workers' Unions upon existing channels of communication", trumpeted the colliery's General Manager in January 1955, "would serve only to weaken the existing medium of negotiation and communication between workers and Management, taking due regard of the characteristic [sic] of the labour force at Wankie." "The whites at Wankie then were as dull as stagnant water", declared a former clerk. "They would not acknowledge the black man."172

But if the colliery's management was reluctant to accept black advancement, some members of the Southern Rhodesian Government reached a very different conclusion. No blushing liberal before or even during the strike, the colony's prime minister, Garfield Todd, thereafter embarked on a series of "multiracial" reforms. These were sufficiently radical so far as settler society was concerned to cause his overthrow by cabinet coup less than four years later. ${ }^{173}$ Yet the challenge posed by black labour to white capital during the strike itself was always somewhat diffuse. In a purely Zimbabwean context, Wankie was remote from the main centres of population and its labour force easily contained at the first signs of trouble, not least because so many of the colliery's workers came from across the Zambezi. Indeed, in many respects, the history of the 1954 strike is as much Zambian as it is Zimbabwean.

16s Ibid., Cabinet minutes, 23 March 1954.

169 Wankie Colliery Company [. . .] Report of the Directors for [. . .] 1954, p. 6.

170 Todd Papers, Cabinet minutes, 3 August 1954.

1" Ibid., "Notes on [. . .] the Wankie Strike. February 1954".

in Interview, A. Kwibisa, Lusaka, 6 April 1990.

in See, variously, N. Shamuyarira, Crisis in Rhodesia (London, 1965); and D. Chanaiwa, "The Premiership of Garfield Todd in Rhodesia", Joumal of Southern African Affairs, 1 (1976). 
Its broader historiographical significance, however, lies in two quite different areas. In the first place, the gendered analysis developed in this paper not only casts the position of women in the 1954 strike into sharp relief, but more importantly, by noting the ambiguity of their behaviour, invites further consideration of the form of patriarchy under construction in the mine compounds and urban areas of Southern Africa. And, secondly, this investigation of a single strike has also tried to direct discussion towards the world of work. For all the sophistication with which historians and others have explored the broad economic imperatives of mining capital, as well as the myriad ways in which labour, especially but not exclusively black labour, was mobilized and controlled, and of course made its own history, ${ }^{174}$ the mining historiography of Southern Africa remains curiously truncated in one key respect. Almost without exception it has largely been confined to the surface. ${ }^{175}$ Students of the subject may know a lot about the historical sociology of the compound, or capital's profitability constraints, but they have little idea of what happened underground. This paper suggests that a historical analysis of underground work practices not only facilitates a nuanced appreciation of technological change and its consequences and here the lateness of Wankie's mechanization compared to Europe and South Africa is startling ${ }^{176}$ - but also illustrates the extent to which the process was contested by workers reluctant to surrender the limited degree of self-regulation wrested from management a decade or so previously. "We knew we must fight", declared Mose Kayombo, "even though those new boers [Anglo American] were very strong to lose."1n

${ }^{174}$ Apart from those studies already mentioned, see, for example, F. A. Johnstone, Class, Race and Gold (London, 1976); A. H. Jeeves, Migrant Labour in South Africa's Mining Economy (Johannesburg, 1985); C. Perrings, Black Mineworkers in Central Africa (London, 1979); and J. Higginson, $\boldsymbol{A}$ Working Class in the Making. Belgian Colonial Labour Policy, Private Enterprise, and the African Mineworker, 1907-1951 (Madison, 1989).

${ }^{175}$ Notable exceptions would include Burawoy, "The Hidden Abode of Underdevelopment"; and J. Guy and M. Thabane, "Technology, Ethnicity and Ideology: Basotho Miners and Shaft-sinking on the South African Gold Mines", Journal of Southern African Studies, 14 (1988).

${ }^{176}$ See, for example, I. Steinisch and $K$. Tenfelde, "Technological Change and Social Adjustment in the German Mining and Steel Industries (19th and 20th Centuries)", Innovation Technologique et Civilisation (1989); and B. Fine, The Coal Question. Political Economy and Industrial Change from the Nineteenth Century to the Present Day (London, 1990).

${ }^{\prime n}$ Interview with Mose Kayombo, Zambezi, 19 March 1990. 